<原 蓄 $>$

\title{
慢性肝性脳症における血中および腹水中 アンモニア値の臨床的検討（第一報）
}

$\begin{array}{llll}\text { 熊田 } & \text { 博光 } & \text { 竹内 } & \text { 和男 } \\ \text { 中島 } & \text { 正男 } & \text { 它場 } & \text { 映士 }\end{array}$

要 旨 : 腹水を伴なった肝硬変例18例の静脈血中アンモニア值と腹水中アンモニア值を測定し， 比較したところ15例 $(83 \%)$ に腹水中アンモニア值が，静脈血中アンモニア値より高值を示した.

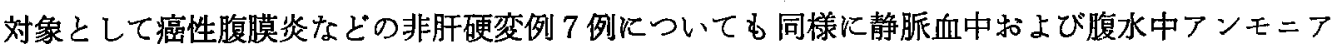
值を測定したところ，肝硬变群とは，逆に 7 例中 5 例 $(71 \%$ ）に静脈血中アンモ二フ值が腹水中 アンモニア值より高值を示した $(\mathrm{p}<0.05)$. 今回の我々の検討では, 肝硬変の際, 腹水中アンモ ニア値が静脈血中アンモニア值に比し高いため，一度に大量の腹水が血中に潅流されると，腹水 中の高いアンモ=アが血中に入り，ひいては静脈血中アンモニア值を上昇させることも肝性脳症 を起こす 1 つの原因になると考えられた.

索引用語： アンモニア值（静脈血中） アンモニア值（腹水中） 腹腔一大静脈シャント 肝性脳症

\section{I. 腥 言}

肝硬変火併存する腹水は，利尿郕の開発，血漿アルブ ミン製剤の投与などにもかかわらず，治療上困難な場合 が少なくない，一方，肝硬変にみられる肝性脳症は予後 不良の兆候とされ，その原因の一つとして古くから血中 フンモニフ值が重要視されている1,2).

また，腹水を伴なった肝硬変例に対して，一度に大量 の利尿がついたり，また腹水を大量洮除すると，肝性 脳定を誘発することが，古くから知られ，その原因に関 しては，電解質の異常なと，種々の原因が考えられてい る.

最近では，肝性脳症の発現に低級脂肪酸の関与む問題 にされている。

治療面では，腹水濃縮再輸注法が開発され，さらに一 歩進んで腹水を直接に大静脈系に潅流させる事により腹 水の調節とアルブミンの血中へ還流が行なわれるように なった.

我々は，難治性腹水に対して Leveen により開発され

*虎の門病院消化器科

<受付日54年12月26日 >
た腹姐一大静脈シャント法 ${ }^{3,4,5)}$ (以下 P-V シャント法) を施行することにより，腹水の軽減をはかってきだ。 今回, 静脈血中アンモニア（以下血中アンモニア）值 が正常範囲にありながら，P-Vシャント施行後一過性の 肝性脳症を来した症例を経験した。この事実に注目し， 腹水を伴なった肝硬変症例の血中アンモニア值と腹水中 アンモニア值の測定を同時に行なったところ，明らか に，腹水中アンモニア值は，血中アンモニア值に比して 著しく高值であることがかかったので，その郜床的意義 について若干の考察を加えて報告する.

\section{II. 対象および方法}

昭和52年 4 月から昭和53年 5 月までに，虎の門病院に 入院した腹水を伴なった肝硬変括よび肝癌18例を対象と した. 対象18例中15例は男性，3 例は女性であり，平均 年龄は男性60歳，女性59歳であった。診断は生存例 8 例 については，腹选鏡拉よび肝生検にて，又，死亡例10例 については，全例剖娭により診断を確定した. アンモ二 ア值は血中，腹水中共に板東変法を用して測定した。当 院のアンモニフ値の正常値は 6 68r/d $l$ である. 腹腔一 大静脈シャントは Leveen 方法にシャント量を調節する ため，樋上らの方法により胸骨前皮下に調節バルブを植 
Y.A. 60y 占 Liver cirrhosis $(\mathrm{HBsAg} \oplus)$ D.M.Diabetic nephropathy

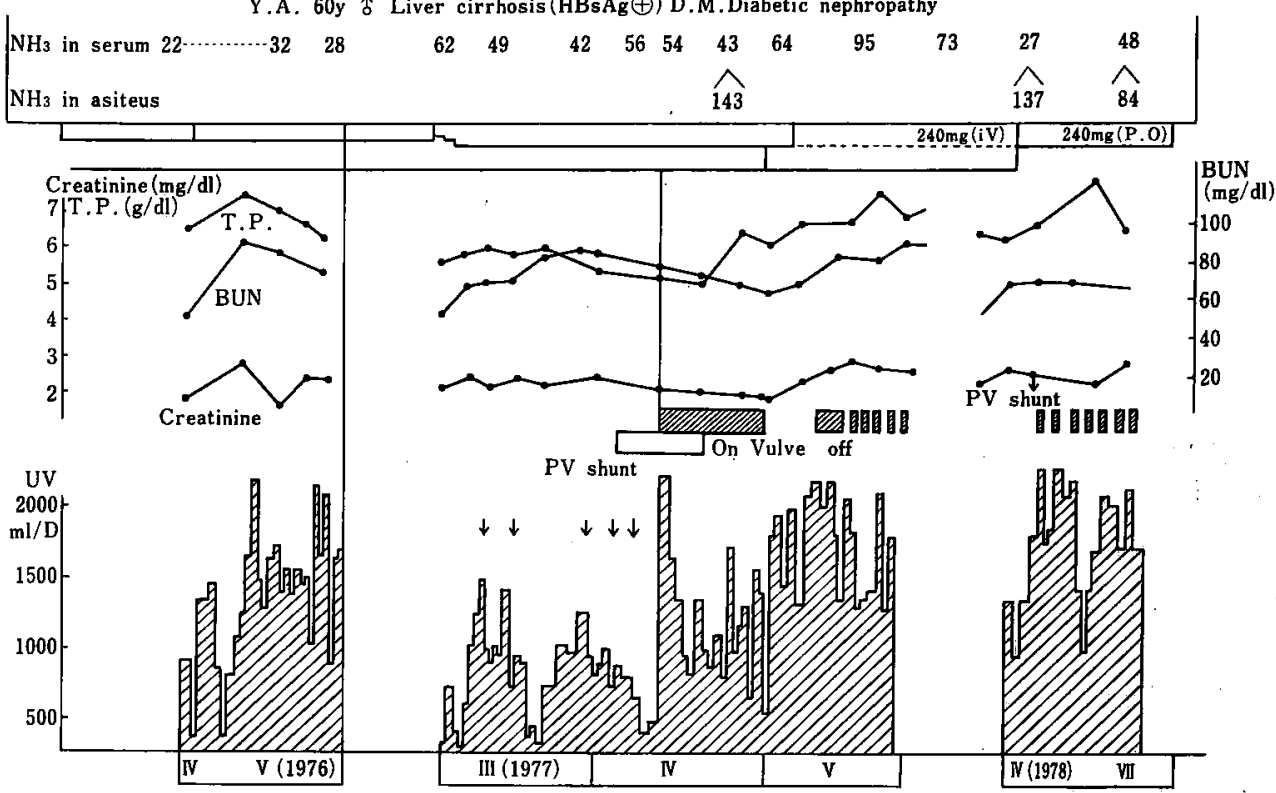

Fig. 1 Course of case A-13

え込んた。

\section{III. 成 續}

1) 肝硬変例について

a) 発端となった症例

まず最初に，今回我々が経時的に腹水中アンモニアと 血中アンモニアを測定し，その比較を行なら直接の動機 となった症例を呈示する (Fig. 1).

症例. ○沢○雄, 60歳, 男性, 会社役員

主訴: 腹水

既往歴：特記すべさとなし，飲酒，少量

家族歷：肝疾患なし，糟尿病なし

現病歴：昭和45年春，口渴，多飲出現 $\mathrm{L}$ ，当院外来受 診し，糖尿病および腹水を指摘されたが，糖尿病に関し ては食事療法にて，腹水に関しては利尿剤によりコント ロールされていた，昭和 49 年 3 月になり，腹水，下腿浮 腫が増強したため，当院第 1 回入院し，腹腔鏡，肝生㭘 などにより，HBs 抗原陽性の肝硬変，糖尿病性腎症と 診断した。昭和50年 5 月難治性の腹水貯留に対して，腹 水濃縮再輸注法を 2 回行ならなどして，腹水のコントロ ールを行なってきた，しかし，昭和52年 3 月には，利尿 剤にも反応が覀くなり，乏尿が出現したため，昭和52年 3 月 3 日，第 4 回入院をした。入院時，体重は74kg，腹 井は $115 \mathrm{~cm}$ ，尿量は500ml/日以下で，4日〜 5 日に一度
に $7 l$ bの腹水を除去 しなければならない状態であっ た. 血液生化学検査では，血中アンモニア値は62r $/ \mathrm{d} l$ と 正常範囲で，BUN 43mg，クレアチニン $2.3 \mathrm{mg} / \mathrm{d} l ， 24$ 時

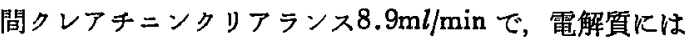
異常を認めなかったまた肝機能は，TP $5.7 \mathrm{~g} / \mathrm{d} l, \mathrm{~A} / \mathrm{G}$ 0.6 , TTT 2.6, ZST 10, 総ビリルビン $0.2 \mathrm{mg} / \mathrm{d} l$, Al-P 4.2, GOT 16, GPT 6, LDH 137, Cho-E 0.3, コレス テロール117mg/d $l$ であった (Table 1).

大量の腹水に対して, 昭和52年 4 月 9 日，第 1 回 P-V シャントを施行した，P-Vシャント施行後との日より 1 日 $1500 \mathrm{~m} l$ 以上の利尿がついた，しかし，P-V シャント 施行 6 時間後にそれまで全く認められなかった羽ばたき 振䁰，記銘力低下等が出現し，顔面浮隀，血圧の上昇む 認められた。そこで我々は，P-Vシャント啳の羽ばたき 振缡などの肝性脳症症状の出現に疑問をいだき，P-V シ ヤント施行 3 日後の 4 月12日，血中アンモ $=ア$ 值と腹水 中アンモニア值を测定したところ，血中アンモニア値が $43 \mathrm{r} / \mathrm{d} l \quad$ 亡正常值にるかかわらず，腹水中アンモ二ア值は $143 \mathrm{r} / \mathrm{d} l$ と異常高值であった。その後, シャントのバル ブを 1 日おきに off-on を調節することにより，羽ばた き振䕱等の症状は出現せず，利尿もつき体重 $65 \mathrm{~kg}$ に腹 囲106cm に減少し，昭和52年 5 月25日退院した。その 後, 経過良好であったが，昭和53年正月頃より，P-V シ ヤントが潅流不全となり，腹水も増強したため，昭和53 
Table 1. Laboratory finding of case A-13

\begin{tabular}{|c|c|c|c|c|c|c|}
\hline Y.A. 60y. M. & $(1977,3,3)$ & Total cholesterol & $117 \mathrm{mg} / \mathrm{d} l$ & \multirow{2}{*}{\multicolumn{2}{|c|}{ STS/TPHA }} & $-1-$ \\
\hline Total protein & $5.7 \mathrm{~g} / \mathrm{d} l$ & Total bilirubin & $0.2 \mathrm{mg} / \mathrm{d} l$ & \multirow{2}{*}{\multicolumn{2}{|c|}{$\begin{array}{l}\mathrm{Hb} \\
\mathrm{RBC}\end{array}$}} & $8.2 \mathrm{~g} / \mathrm{d} l$ \\
\hline Alb. & $41.0 \%$ & $\mathrm{Ch}-\mathrm{E}$ & 0.3 & & & $311 \times 10^{4}$ \\
\hline$\alpha_{1}$-glob. & 3.3 & GOT & 16 & \multicolumn{2}{|c|}{ Platelets } & $12.7 \times 10^{4}$ \\
\hline$\alpha_{2}$-glob. & 8.1 & GPT & 6 & \multicolumn{2}{|c|}{ Urine / Protein } & $44 \mathrm{mg} / \mathrm{d} l$ \\
\hline$\beta$-glob. & 8.7 & $\mathrm{LDH}$ & 137 & & Sugar & - \\
\hline$\gamma$-glob. & 38.6 & $\gamma$-GTP & $32 \mathrm{mU} / \mathrm{d} l$ & \multicolumn{2}{|r|}{ Urobilinogen } & $H$ \\
\hline TTT & $2.6 \mathrm{u}$ & $\mathrm{S}-\mathrm{NH}_{3}$ & $62 \gamma / \mathrm{d} l$ & \multicolumn{2}{|r|}{ Sediment } & normal \\
\hline ZST & $10.0 \mathrm{u}$ & Protrombin time & $83 \%$ & \multicolumn{2}{|c|}{$24 \mathrm{cch}$} & $8.9 \mathrm{ml} / \mathrm{min}$ \\
\hline BUN & $43 \mathrm{mg} / \mathrm{d} l$ & Trombotest & $100 \%$ & \multicolumn{2}{|c|}{ Ascites } & \\
\hline Creatinine & $2.3 \mathrm{mg} / \mathrm{d} l$ & $\mathrm{HBsAg} / \mathrm{Ab}$ & $+\angle-$ & \multicolumn{2}{|c|}{ Gravity } & 1011 \\
\hline $\mathrm{Na}$ & $150 \mathrm{mEq} / l$ & AFP & $(-)$ & \multicolumn{2}{|c|}{ Rivata reaction } & - \\
\hline K & $4.8 \mathrm{mEq} / l$ & ESR & $26 \mathrm{~mm} / \mathrm{hr}$ & \multicolumn{2}{|c|}{ Protein } & $1.6 \mathrm{~g} / \mathrm{d} l$ \\
\hline $\mathrm{Cl}$ & $113 \mathrm{mEq} / l$ & CRP & $(+)$ & \multicolumn{2}{|c|}{ Bucteria } & - \\
\hline
\end{tabular}

年6月21日，P-Vシャント再建のため第 5 回入院した。 今回は, P:V シャント施行前の血中アンモニフ値 $27 \mathrm{r} / \mathrm{d} l$, 腹水中アンモニア值 $137 \mathrm{r} / \mathrm{d} l$ と前回よりる低值であった ことと,バルブの on-off 調節を行ない大量の腹水の潅 流を避けたためか肝性脳症などの症状は出現しなかっ た. そしてP-V シャント施行後 2 日目の血中アンモ二 ア値は $48 \mathrm{r} / \mathrm{d} l$, 腹水中アンモニア値は $84 \mathrm{r} / \mathrm{d} l$ と混和された 值を呈した。昭和53年 7 月11日に退院し, 現在に至るま で腹水堌強, 肝珄脳症症状はない。

b ）消化管出血後に腹水が詝留した症例

次に，代償期の肝硬変で多発性胃びらんより出血後， 腹水が著明に眝留し，その血中アンモニア值は軽度異常 を示したのみで，腹水中アンモニア值が異常に高值を示 した症例を呈示する (Fig. 2)。

症例. ○々○章, 59歳, 男性, 会社員

既往歴：32歳肺結核。輸血歷なし，

家族歴：特記すべきことなし.

現病歴：昭和46年春, 健康診断で肝炎といわれたが放 监. 昭和48年再び, 肝障害を指摘され某病院に40日入院 したが，データの改善はなかった．昭和49年より外来に て経過観察したが，改善がないため昭和51年11月から昭 和52年 3 月までコルチコステロイド剤の投与を受けてい た．昭和52年 4 月，転勤になり当院外来受診し，精查の ため昭和52年 12 月 5 日入院した，入院時全身状態良好 で, 自覚症状は全くなかった。肝葴は 3 横指触知し, 辺 縁鈍で脾臓は 1 横指触知した.くる状血管腫，手掌紅斑 も認められた，血液生化学検査では電解質には異常な ২, TP $8.0 \mathrm{~g} / \mathrm{d} l, \mathrm{~A} / \mathrm{G} 1.1$, TTT 12.4, ZST 11.0 , BUN 19 , クレアチニン $0.9 \mathrm{mg} / \mathrm{d} l$, 総ビリルビン $1.1 \mathrm{mg}$ l
A.S. 59y \& Liver cirrhosis

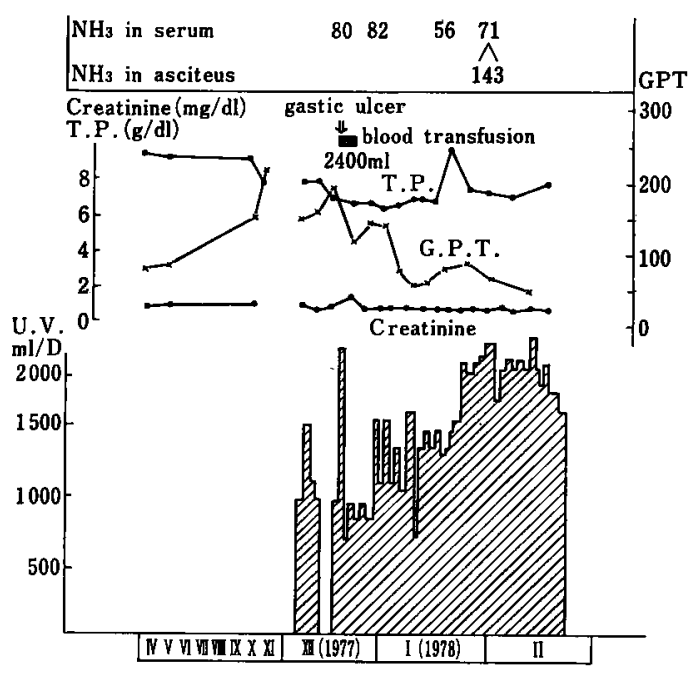

Fig. 2 Course of case A-14

$\mathrm{d} l, A l-P$ 6.9, コリンエステラーゼ0.5, 総コレステロ ール188, GOT 197, GPT 145, LDH 145であり検查上 肝硬変と考えられた (Table 2).

昭和 52 年 12 月 16 日，腹腔鏡肝生検を施行し，肝硬変 (長与のZ型) と診断され，現在は々の代償期と考えら れた. 12月18日早期になり大量のタール便を認めたので 内視鏡を施行したところ，多発性胃びらんよりの出血で あることが確認された．保存血 $2,600 \mathrm{ml}$ を輸血し，経 過観察していたところ出血後 2 日目の12月20日より腹部 膨満感が出現し徐々に増強し，腹水貯留が認められた。 下血は出血後 5 日目の12月23日より黄色便に変わった 
Table 2. Laboratory finding of Case A-14

\begin{tabular}{|c|c|c|c|c|c|}
\hline A.S. 59y. M. & $(1977.12 .5)$ & $\mathbf{K}$ & $4.8 \mathrm{mEq} / l$ & RA & $1 \cdot(+)$ \\
\hline Total protein & $8.0 \mathrm{~g} / \mathrm{d} l$ & $\mathrm{Cl}$ & $109 \mathrm{mEq} / l$ & STS/TPHA & $+/+$ \\
\hline Alb. & $58.5 \%$ & Total cholesterol & $188 \mathrm{mg} / \mathrm{d} l$ & $\mathrm{Hb}$ & $14.8 \mathrm{~g} / \mathrm{d} l$ \\
\hline$\alpha_{1}$-glob. & $2.1 \%$ & Total bilirubin & $1.1 \mathrm{mg} / \mathrm{d} l$ & $\mathrm{RBC}$ & $451 \times 10^{4}$ \\
\hline$\alpha_{2}$-glob. & $6.1 \%$ & Ch-E & 0.5 & WBC & 6500 \\
\hline$\beta$-glob. & $7.9 \%$ & GOT & 197 & Platelet & $6.0 \times 10^{4}$ \\
\hline |r-glob. & $25.1 \%$ & GPT & 145 & & \\
\hline $\mathrm{A} / \mathrm{G}$ & 1.1 & $\gamma$-GTP & 134 & Urine & \\
\hline TTT & $12.4 \mathrm{u}$ & $\mathrm{HBsAg} / \mathrm{Ab}$ & $-1-$ & Protein & $(-)$ \\
\hline ZST & $11.0 \mathrm{u}$ & AFP & $(-)$ & Sugar & $(-)$ \\
\hline BUN & $19 \mathrm{mg} / \mathrm{d} l$ & ESR & $6 \mathrm{~mm} / \mathrm{hr}$ & Urobilinogen & $(+)$ \\
\hline $\mathrm{Na}$ & $144 \mathrm{mEq} / l$ & CRP & $(-)$ & Sedimet & normal \\
\hline
\end{tabular}

が，腹部膨隆は逆に進行していった．昭和53年 1 月21 日，血中および腹水中アンモニア值を測定したところ， 血中アンモニア值は71r/d $l$ と軽度の異常を示したが，そ れに対し，腹水中アンモニア値は143r/d $l$ と血中アンモ ニア値の 2 倍以上の高值であった．腹囲，体重等の全身 状態は昭和53年 1 月10日を極值として軽快し，1月24日 には内視鏡にて胃びらんが治疻したのを確認し，2月10 日軽快退院した，本例の経過中の血中アンモニア値は $51 \mathrm{r} / \mathrm{d} l \sim 82 \mathrm{r} / \mathrm{d} l$ と軽度の異常值を示しながらす変動はむ しろ少なかった.

以上，本症例は代償期の肝硬変に，多発性胃びらんが 出現し，腸管内に多量の血液が入り，血中アンモ二ア值 が上昇すると思われたが，腹水が貯留し血中アンモニア を腹水中に逃がすことにより，血中アンモニア值の上昇 を防ぎ，肝性脳症の発現をみなかったと考学られる。

c) 肝硬変, 肝癌18例の検討

さきに呈示した症例に拈いて，腹水中アンモニア值が 血中アンモニア値に比して異常な高値を示したため，腹 水を伴なった肝硬変, 肝癌18例症例について血中アンモ ニア值と腹水中アンモニア値を比較した（Table 3).

肝硬変, 肝癌18例中症例 A-1〜A-15までの15例は腹水 中アンモニア値〉血中アンモニア值であった．また血中 アンモニア值が正常範囲にありながら, 腹水中アンモ二 ア値が異常を呈した症例が10例む認められた。しかも腹 水中アンモニア值が血中アンモニア值の 2 倍以上の症例 が 7 例 (A-4, 8, 9,10,13,14,15) 認められた。肝 硬変例のみに限ると，5例全例が腹水中アンモニア 值 >血中アンモキア值ですった。一方，A-16〜A-180 3 例 はいずれも肝硬変を伴なった肝癌例で腹水中アンモニア 値く血中アンモニア値であったが，この3例のうちA-
16とA-18は，肝門部に癌が浸潤したために, 閉塞性黄病 をきたしていた症例であった。また，腹水中アンモニア 値及び血中アンモニア值のいずれる正常範囲内の症例 は，1例のみで，病勢の進行と共に異常高値を呈した。

HBs 抗原例は6 例 (40\%)， HBs 抗体は 5 例 (33\%) に認められたが, HBs 抗原抗体の有無と腹水中および血 中フンモニア值については，特に関係は認められなかっ た.また，ICG は6〜68\%，BSP は10〜30\%と種々の值 を呈したが, アンモニア值とは特に関係は認められなか った.

2) 非肝硬変例について

a) 非肝便変 7 例の検討

肝硬変, 肝癌症例と対比するため, 肝硬変肝癌以外の 原因によると考えられる癌性腹膜炎に伴なった腹水症例 についても同様の検索を行なった (Table 4). 非肝硬変 例 (B群) 7 例では，5例 (71\%) が血中アンモ=ア值 >腹水中アンモニア値であり, 肝硬変群と逆の関係を示 した。また B-6，B-7の 2 例は腹水中アンモニア值>血 中アンモニア值であったが，この 2 例は腹水中フンモ= ア值を測定した時点で，すでに $\mathrm{S}$ 字状結腸癌が広範に肝 転移を起した状態にあり，癌の転移による肝不全の状態 であった。

b ) 胆露癌, 癌性腹膜炎症例

次に肝転移により，末期に肝性脳症が出現した胆庄癌 の癌性腹膜炎の症例 (B-2) が, 肝転移が進行するにつれ て，血中アンモニアと腹水中アンモニアが興味古る動き を示したので呈示する (Fig. 3).

症例. $\bigcirc$ 部 $\mathrm{O}$ 越, 71歳, 男性.

主訴 : 右側腹部痛

家族歷 : 兄肝疾患. 
Table 3. Comparison $\mathrm{NH}_{3}$ in serum with $\mathrm{NH}_{3}$ in ascites of liver cirrhosis

\begin{tabular}{|c|c|c|c|c|c|c|c|}
\hline \multicolumn{2}{|c|}{ Case } & Age & Sex & Clinical diagnosis & $\begin{array}{l}\text { Pathological } \\
\text { diagnosis }\end{array}$ & ICG $15(\%)$ & $\underset{\text { (serum) }}{\mathrm{NH}_{3}} \underset{\text { (asites) }}{\mathrm{NH}_{3}}$ \\
\hline$* * \mathrm{~A}-1$ & M. K. & $58 y$ & $\mathbf{M}$ & $\mathrm{LC}+\mathrm{H}$ & $\mathrm{LC}+\mathrm{H}$ & $63 \%$ & $67<119$ \\
\hline$* * A-2$ & S. K. & $58 y$ & $\mathbf{M}$ & $\mathrm{LC}+\mathrm{H}$ & $\mathbf{L C}+\mathbf{H}$ & $49 \%$ & $53<87$ \\
\hline$* * \mathrm{~A}-3$ & U. W. & $62 y$ & $\mathbf{M}$ & $\mathbf{L C}+\mathbf{H}$ & $\mathbf{L C}+\mathbf{H}$ & $48 \%$ & $42<47$ \\
\hline$* * \mathrm{~A}-4$ & s. o. & $63 y$ & $\mathbf{M}$ & $\mathrm{LC}+\mathrm{H}$ & $\mathbf{L C}+\mathbf{H}$ & $6 \%$ & $58<110$ \\
\hline$* * A-5$ & S. S. & $59 y$ & $\mathbf{M}$ & $\mathrm{LC}+\mathrm{H}$ & $\mathrm{LC}+\mathrm{H}$ & $43 \%$ & $73<113$ \\
\hline$A-6$ & J. K. & $77 y$ & $\mathbf{M}$ & $\mathrm{LC}+\mathrm{H}$ & $\mathbf{L C}+\mathbf{H}$ & $60 \%$ & $68<$ \\
\hline$* * A-7$ & K. S. & $33 y$ & $\mathbf{M}$ & $\mathbf{L C}+\mathbf{H}$ & Alive & $49 \%$ & $33<$ \\
\hline$A-8$ & S. S. & $59 y$ & $\mathbf{M}$ & $\mathrm{LC}+\mathrm{H}$ & Alive & $38 \%$ & $36<145$ \\
\hline${ }^{* *} A-9$ & I. N. & $61 y$ & $\mathbf{M}$ & $\mathrm{LC}+\mathrm{H}$ & Alive & $33 \%$ & $63<144$ \\
\hline$A-10$ & J. N. & $60 y$ & $\mathbf{M}$ & $\mathbf{L C}+\mathbf{H}$ & Alive & $(-)$ & $24<$ \\
\hline$A-11$ & N. S. & $59 y$ & F & LC & LC & $74 \%$ & $87<129$ \\
\hline$A-12$ & $\mathrm{~T} . \mathrm{N}$. & $55 y$ & $\mathrm{~F}$ & $\mathrm{LC}$ & LC & $(-)$ & $107<172$ \\
\hline$* * A-13$ & Y.A. & $61 y$ & $\mathbf{M}$ & $\mathrm{LC}$ & Alive & $(-)$ & $45<135$ \\
\hline$A-14$ & A. S. & $59 y$ & $\mathbf{M}$ & LC & Alive & $31 \%$ & $71<143$ \\
\hline$A-15$ & M. K. & $63 y$ & $\dot{M}$ & LC & LC & $32 \%$ & $48<94$ \\
\hline${ }^{*} \mathrm{~A}-16$ & T. S. & $65 y$ & F & $\mathrm{LC}+\mathrm{H}$ & Alive & $48 \%$ & $110>41$ \\
\hline${ }^{* *} \mathrm{~A}-17$ & M. I . & $71 y$ & $\mathbf{M}$ & $\mathrm{LC}+\mathrm{H}$ & Alive & $33 \%$ & $75>67$ \\
\hline$* A-18$ & N. N. & $46 y$ & $\mathbf{M}$ & $\mathrm{LC}+\mathbf{H}$ & $\mathrm{LC}+\mathrm{H}$ & $(-)$ & $110>67$ \\
\hline
\end{tabular}

Table 4. Comparison $\mathrm{NH}_{3}$ in serum with $\mathrm{NH}_{2}$ in ascites of non-liver cirrhosis

\begin{tabular}{|c|c|c|c|c|c|c|c|}
\hline \multicolumn{2}{|c|}{ Case } & Age & Sex & Clinical diagnosis & Pathological diagnosis & ICG $15^{\prime}(\%)$ & $\underset{\mathrm{NH}_{3}}{\mathrm{Nerum}_{\text {) }}} \underset{\text { (asites) }}{\mathrm{NH}_{3}}$ \\
\hline B- 1 & $\mathrm{~T} \cdot \mathrm{O}$ & $69 y$ & $\mathbf{F}$ & Gall bladder cancer & Gall bladder cancer & $31 \%$ & $96>63$ \\
\hline B -2 & K. A. & $71 y$ & $\mathbf{M}$ & Gall bladder cancer & Gall bladder cancer & $7 \%$ & $64>38$ \\
\hline$B-3$ & N. M. & $44 y$ & $\mathbf{F}$ & Choledocal cancer & Choledocal cancer & $(-)$ & $58>57$ \\
\hline$B-4$ & $\mathrm{Y} . \mathrm{W}$. & $38 y$ & $\mathbf{M}$ & Chronic renal failure & Alive & $(-)$ & $47>45$ \\
\hline$B-5$ & N. U. & $18 y$ & $\mathbf{F}$ & Pineoloma & Alive & $(-)$ & $36>15$ \\
\hline$* \mathrm{~B}-6$ & H. T. & $74 y$ & $\mathbf{F}$ & Siymoid cancer & Siymoid cancer & $(-)$ & $49<64$ \\
\hline$* \mathrm{~B}-7$ & Y. N. & $65 y$ & $\mathbf{M}$ & Pancreas cancer & Pancreas cancer & $(-)$ & $116<246$ \\
\hline
\end{tabular}

* : Liver metathesis

既往歴：特記すべきことなし.

現病歴：昭和43年春，右季肋部痛のために入院し，胃 炎といわれた．昭和52年 1 月右季肋部の激痛のために救 急病院に入院し，虫垂炎として手術したが，手術後も季 肋部痛が軽快しないため, 昭和52年 3 月当院受診 L， 3 月 7 日腹腔鏡により，胆褒癌および肝転移と診断した。 家族の希望により，丸山ワクチンを投与していたが，昭 和52年11月になり徐々に腹水貯留したため，11月 3 日
第 2 回入院となった. 入院時, 腹水は著しく眝留し， TP $6.7 \mathrm{~g} / \mathrm{d} l$, A/G $0.7, \gamma$-glob $30.9 \%$, TTT 1.5, ZST 6.2, 総ビリルビン2.0mg/d $l$, Al-P 44, Cho-E 0.3, GOT 47, GPT 12, LDH 499, BUN $42 \mathrm{mg} / \mathrm{d} l$, クレアチニン $1.3 \mathrm{mg} / \mathrm{d} l$, また血中アンモニア值は $64 \mathrm{r} / \mathrm{d} l$, 腹水中アン モニア值は38r/d $l$ であった (Table 5). 入院後, 腹部膨 満が強く 4 日〜 5 日に一度の割で腹水を排除しなければ ならない状態であったので，11月15日，P-V シャントを 
K.A. 71y \& Diagnosis $\mathrm{Ca}$ of Gall bladder

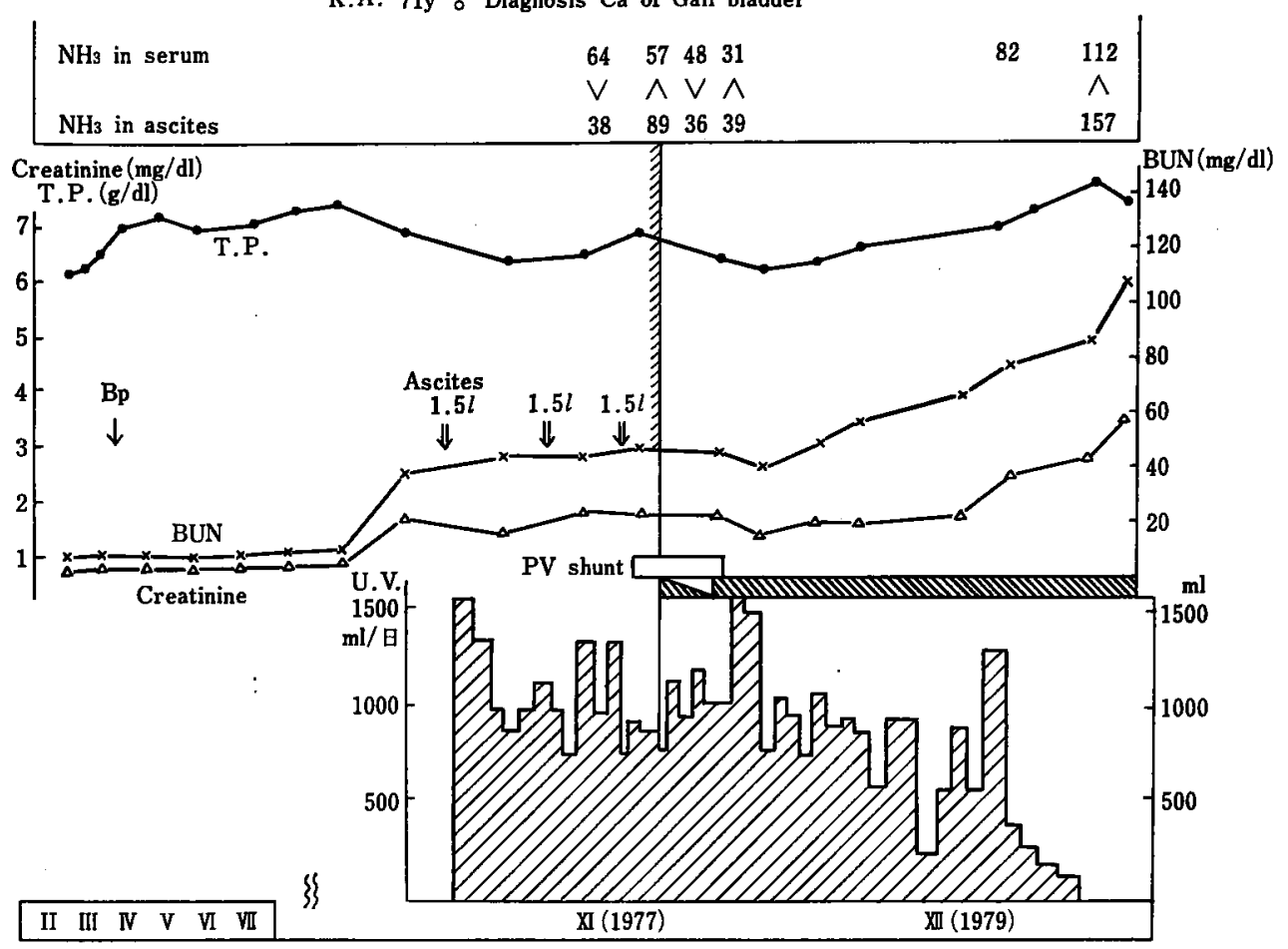

Fig. 3 Course of case B-2

Table 5. Laboratory finding of Case B-2

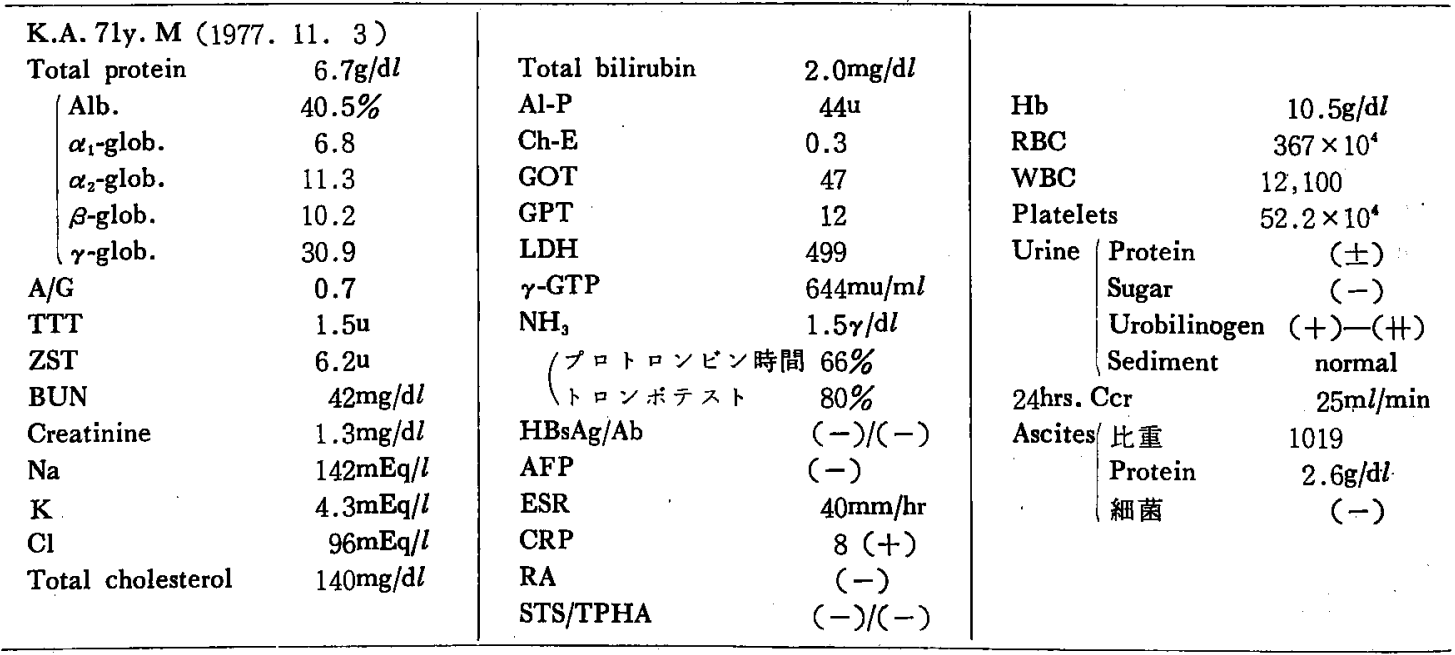


施行したシャント施行前日の血中フンモニア值は57 $r / \mathrm{d} l$, 腹水中アンモニア值は89r/d $l$ とすでに腹水中アン モ二ア值が高かった。しかし，シャント後は1日目を除 いて，腹水中アンモニア值が血中アンモニア值より高 く，末期には血中，腹水中共に異常高値を示した。

\section{IV. 考案}

血中アンモニアと肝性昏睡の関連性については，古く は1932年に，Van Caulaert に上り最初㑢告され，注 目を浴びたが，必ずしも血中アンモニア值のみで肝性脳 症を説明することはできず，電解質異常》や，血中の低 級脂肪酸息，他のアミン酸などによってる誘発される。 しかし, 血中アンモ二ア值は, 肝性脳症の 1 つの指標に なることはゆがめない。

一方, 難治性腹水に対し，腹水再輸注法が Gullop ら ${ }^{9}$ により発表されて以来，多くの報告がある．さらに， 1971年に Levyにより ${ }^{10)}$ ，血液透析を利用して腹水濃縮 再輸法が開発され，本邦でもその有効が認められてい る.

近年，Leveen により開発された P-V シャントが， 持続的に腹水を大静脈に潅流し，難治性腹水に対して， 治療効果をあげている ${ }^{3,4,5)}$ ．今回，我々は，この Leveen の P-V シャントを難治性腹水を伴なった肝硬変例に 施行したところ，一過性の肝性脳症症状が出現した。 そ こで, 腹水を伴なった肝硬変例の血中と腹水中のアンモ ニフ値を比較したところ，18例中15例 $(83 \%)$ K，腹水 中アンモニア值〉血中アンモニア值の関係が認められ た．今回我タが経験した症例 A-13に拄いて P-Vシャン 卜施行後，一過性の肝性脳症を発生させたことは，直接 腹水を血中に潅流させたことにより，高い濃度の腹水中 のアンモニアが血中に入ったためと推測される。これま で，腹水中アンモニアと血中アンモニアを比較した報 告はあるが(14)，その意味については十分解明されていな い.

今回我々の報告は， 3 例を除いて $83 \%$ に腹水中アンモ ニア値が血中フンモニフ值より高かった. 最近行なわれ ている血液透析を利用しての腹水再輸注法の場合には， 血中アンモニアは腹水輸注前後，大差はみられない報告 $は^{11,12,13,16)}$ あるが，Leveen のP-Vシャント施行前後の 血中アンモニフについて言及した報告はない，今後， $\mathrm{P}-\mathrm{V}$ シャント施行際には，事前飞腹水中アンモ二フ值 を考慮に入れ，慎重を期すべきと思われる，肝硬変の場 合，この腹水中アンモニア值が血中アンモニア值より高 い原因については, 一種の生体防禦機構とも考えられ,
血中フンモニア值が高く，肝性脑症を起こすことを避け るため，腹水中にアンモニアを移行させることにより， 血中アンモニフの上昇を防いでいるかもしれない。

一方, 肝硬変肝癌で腹水中アンモ二フ值が血中アンモ ニア值より低值であった症例が 3 例認められたが，この 万ち A-16, A-18の 2 例は肝癌が肝門部一浸潤し, 閉塞 性黄疸を呈していた。閉塞性黄疸の際，肝細胞のアンモ こフ処理能力が著しく低下することは，すでに報告され ておりここの 2 例む閉塞性黄疸による肝細胞でのアンモ ニア処理が悪く，血中にアンモニアが逆流したとも考克 られる ${ }^{16)}$.

また肝硬変群と比較対象として呈示した非肝硬変群で は， 7 例中 5 例が腹水中アンモニア値く血中アンモニア 值であったが，この事実は，癌性腹膜炎による腹水は， 単なる反応性渗出であると考えられる。肝硬变群と同様 に，腹水中アンモ二ア值〉血中アンモニア值であった 2 例では，癌の転移による症例であり，呈示した症例 (B-2) は，肝転移が進行するにつれ初期の腹水中アンモ ニフ值く血中アンモニフ值の関係が，末期になり肝性脑 症症状を呈した時期纪は腹水中フンモニア值〉血中フン モニア值の関係になっていた。しかし，肝性昏睡の原因 とついては，アンモニア代謝の他に低級脂肪酸の関与，

電解質異常によっても誘発されることが知られているの で，今後腹水中の低級脂肪酸の值なども測定する必要が あると思われる。

\section{V. 結 語}

1）腹水を伴なった肝硬变症患者の血中アンモ二ア値 と腹水中アンモ $=$ 值の比較では，18例中15例 $(83 \%)$ が有意に腹水中アンモニア值が高かった。

2）原病が非肝疾患群 7 例では，5例 $(71 \%)$ は血中 アンモニア值>腹水中アンモニア值であり，腹水中アン モニア值が血中アンモニア值より高かった 2 例では，癌 の肝転移の進行による症例であった。

（本論文の要旨㤌第65回消化器病学会総会で発表し t. )

\section{文献}

1) Castell, D.O. et al.: Ammonia absorption from the human colon. Gastroenterology, 60: 33, 1971.

2) White, L.P. et al.: Ammonium tolerance in the liver disease. Observations based on catheterization of the hepatic veins. J. Cli. I. Invest., 34: 
$158,1955$.

3) Leveen, H.H. et al.: Further experience with peritoneovenous shunt for ascites. Ann. Surg., 184: $574,1976$.

4) Leveen, H.H. et al.: Peritoneo-venous shunting for asciteus. Ann. Surg., 180: 580, 1974.

5) Wapnick, S. et al.: Leveen continuous peritonealjugular shunt. Improvement of renal function in ascitic patients. JAMA., 237: 131, 1977.

6）樋上 駿他：難治性大量腹水に対寸る腹腔 ・ 大静脈 (P-V) シャント。臨床外科, 32 ： 33, 1977.

7) Sherlock, S. et al.: Complication of diuretic therapy in hepatic cirrhosis. Lnacet., 7446: $1049,1966$.

8）高橋善弥太 : 代謝からみた肝性皆㴈. 紜合臨 牀, $22: 1329,1973$.

9) Adlerreutz, E.: Intraperitoneal infusion of ultrafiltered ascites in decompensated cirrhosis of the liver. Acta. Med. Scand., 161: 9, 1958.

10) Levy, V.G. et al.: Treatment of ascites by reinfusion of concentrated peritoneal fluidReview of 318 proceducers in 210 patients. Postgrad. Med. J., 51 : 564, 1975.

11）板坂勝良他：濃縮腹水再静注を試みた肝硬変の 1 例. 日消誌, $73: 1079,1976$.

12）太田亘也他：腹水再静注による難治性腹水の治 療. 肝臓, $15: 83,1974$.

13）阿岸鉄三他：難治性腹水に対する植え込み式腹 水ポンプの臨床効果. 日本医事新報, 2784 : $27,1977$.

14）井上十四郎：䏦疾患に和ける腹水の性状とその 治療. 医学のあゆみ, 2634：3，1974.

15) 阿岸鉄三他：植え込み式腹水ポンプによる腹水 注入の腎, 肝機能に及隹す効果. 最新医学, $33: 825,1978$.

16) 大和田康夫他：閉塞性黄疸肝におけるアンモニ ア代謝について. 肝葴, $18: 333,1977$. 
Clinical investigations on serum and ascitic ammonium values in chronic hepatic encephalopathy

Hiromitsu Kumada, Kazuo Takeuchi, Eiji Oyake, Masao Nakajima and Akira YoshIBA*

A method of shunting the abdominal cavity and vena cava superior developed by Leveen has been employed of late in a more active treatment of patients with intractable ascites. When we treated patients who had hepatitic cirrhosis with Leveen's method of shunting the abdominal cavity and vena cava superior a transient hepatic encephalopathy developed after treatment.

In an attempt to clarify the cause of this developement, we compared both the serum and ascitic ammonium values obtained from 18 cases of hepatitic cirrhosis accompanied with ascites, and found out that the ascitic ammonium values in 15 cases (83\%) were higher than that of blood.

In contrast to the group with hepatitic cirrhosis, when the serum and ascitic ammonium values obtained from 7 control patients with non-hepatitic cirrhotic diseases such as peritonitis carcinomatosa were studies, 5 out of 7 cases $(71 \%)$ showed higher values of serum ammonium than that of asities.

On the other hand, it has long been known among medical workers that hepatic encephalopathy could be induced when a voluminous diuresis is obtained at one time or removed in a pathient with hepatitic cirrhosis accompanied with asities and that it is conceivaly attributable to abnomal electrolytes including other factors. However, the results obtained from our current investigations have suggested that when a voluminous ascites is perfused with blood at on time, the ascitic ammonium comes into the blood because of its having a higher value than that of blood, thereby raising up the ammonium value of the blood which may cause hepatic encephalopathy.

* Department of Digestive Organs, Toranomon Hospital 